\title{
EXAMINING FORMULAS THAT ASSESS STRENGTH LOSS DUE TO DECAY IN TREES: WOUNDWOOD TOUGHNESS IMPROVEMENT IN RED MAPLE (ACER RUBRUM)
}

\author{
by Brian C.P. Kane ${ }^{1}$ and H. Dennis P. Ryan III ${ }^{2}$
}

\begin{abstract}
Hazard trees are a concern for anyone who manages trees in a landscape setting, including arborists, urban foresters, and grounds managers. Through research, experience, observation, and common sense, arborists and urban foresters have identified many risk factors that predispose trees to failure. They have also developed thresholds to help determine the degree of hazard, whether a tree is in imminent danger of failing or needs annual (or more frequent) inspections. Two critical factors are involved in strength loss assessment in tree stems with defects. First, it is important to know how much tree strength is lost due to a defect such as a hollow or cavity. Second, the load required to cause failure needs to be considered since the wood of some trees can endure greater mechanical stress than others. Tests of woundwood and normal wood in red maple (Acer rubrum) trees from Massachusetts, U.S., showed woundwood to exhibit consistently greater toughness measures compared to normal wood. There was, however, no correlation between the degree of toughness improvement in woundwood and the severity of decay (calculated as the loss in moment of inertia of the stem). Woundwood toughness improvement appears to be an additional safety factor in red maple trees that reduces the risk of failure due to trunk decay.
\end{abstract}

Key Words. Hazard tree; tree moment of inertia; decay; mechanical stress.

Hazard trees are a concern for anyone who manages trees in a landscape setting, including arborists, urban foresters, and grounds maintainers. Considerable time and effort have been spent addressing the problem of assessing the risk of tree failure. Because trees are living organisms, growing in varied environments, it is impossible to predict exactly when a tree will fail. Indeed, tree failures are frequently referred to as "acts of God." Arborists, urban foresters, and others concerned with hazard tree management realize this fact and know that the best way to manage hazard trees is to assess risk factors of the tree and its target. Armed with that information, they then estimate the likelihood of tree failure and damage potential associated with the failure. Through research and experience, arborists and urban foresters have identified many risk factors that predispose trees to failure. They have also developed thresholds to help determine the degree of hazard, whether a tree is in imminent danger of failing or needs annual inspections.

The use of formulas to assess the risk of failure in trees with trunk decay can be traced to Wagener (1963) who suggested that the following formula could be used: $d^{3} / D^{3}$, where $d$ is the diameter of the decayed or hollow area in the tree trunk and $D$ is the diameter of the tree. Many publications cite this formula as a starting point for hazard tree assessment (Mills and Russel 1981; Lucas et al. 1984; Robbins 1986; Albers and Hayes 1993; Matheny and Clark 1994), and it is based on the loss in moment of inertia (I) of a hollow cylinder. Kane et al. (2001) reviewed the formulas currently used by arborists and urban foresters in the United States and also described the connection between the formulas and I. Niklas (1992) offers a more thorough explanation and description of I. As Kane et al. (2001) point out, the formulas in use address stem geometry only to estimate the risk of failure, but load and wood properties should also be considered for a more accurate assessment of risk. As the area of decay increases, I of the tree stem decreases; thus, mechanical stress $(\sigma)$ increases by the formula: $\sigma=M * y / I$, where $I$ is moment of inertia, $M$ is bending moment (a measure of force), and $y$ can be thought of as the radius of the tree at the point where decay is measured.

In this paper, we describe research conducted to determine the difference in wood toughness between woundwood and normal wood. Toughness is a measure of wood brittleness and reflects the work required to cause failure in bending through an impact load (Bodig and Jayne 1982). We have assumed that an improvement in woundwood toughness correlates to a change in woundwood modulus of rupture (MOR), which is a measure of the amount of bending $\sigma$ the wood can endure. An improvement in woundwood toughness, given our assumption of a correlation to MOR, would indicate that the formulas to determine risk of tree failure due to decay might overestimate the risk of failure. This is true because if woundwood can endure greater bending $\sigma$, the increase in bending $\sigma$ due to stem decay would be offset to some degree by the woundwood's ability to endure greater $\sigma$. 
This analysis is true only if surface wounds caused woundwood formation at the spot where an arborist is examining the tree for decay. If no woundwood is present on the stem at that point, then the concern for increased woundwood strength would not apply, and the formulas would not overestimate the risk of failure. Furthermore, if an old surface wound caused woundwood formation that has since been covered by many layers of normal wood formed after the wound closed, the concern for increased woundwood strength would not apply since the outer fibers in a tree stem endure most of the bending $\sigma$.

If we assume that woundwood toughness improvement can also be correlated with woundwood modulus of elasticity (MOE), an increase in toughness would reduce the risk of buckling failure in trees because the risk of buckling failure is inversely proportional to MOE. The increase would also question Wessolly's (1995) use of a mean MOE value for species when using the Elastometer to determine residual carrying capacity of hollow trees versus solid cross sections. Arborists in Europe use the Elastometer to determine risk of tree failure. Although we could not find studies that presented specific relationships between wood toughness and either MOR or MOE, we regressed impact bending test data on MOR data from the Wood Handbook for 84 species (Forest Products Laboratory 1999). The regression analysis showed a relationship of impact bending = $1.82 * \mathrm{MOR}^{1.44}\left(\mathrm{R}^{2}=0.66\right)$, which lends some support to our assumption.

\section{MATERIALS AND METHODS}

We harvested 22 red maple (Acer rubrum) trees with woundwood formed around logging wounds from two similar sites (11 trees per site) in western Massachusetts, U.S. (USDA hardiness zone 5a). We also harvested five control trees without any woundwood or decay from each site, for a total of ten control trees. Before harvesting, we marked compass north on each trunk and numbered each tree. In addition to thick woundwood formation around wounds, trees had adjacent normal wood formed where there was no decay in the trunk. Figure 1 shows a typical tree used for sampling. Control trees were similarly numbered and marked with compass north. We used control trees to test for axial distance toughness differences between samples. This was necessary because all woundwood samples were taken from lower on the trunk than normal wood samples, and the height at which samples are taken from a tree can influence wood properties (Panshin and DeZeeuw 1980).

Since we were not interested in site effects on toughness measures, we grouped all 22 treatment trees together to increase statistical power. From each treatment tree, we cut two bolts of wood, one with woundwood, and one without any woundwood. From each bolt of wood, we took three samples, one from each side of the wound, presumably

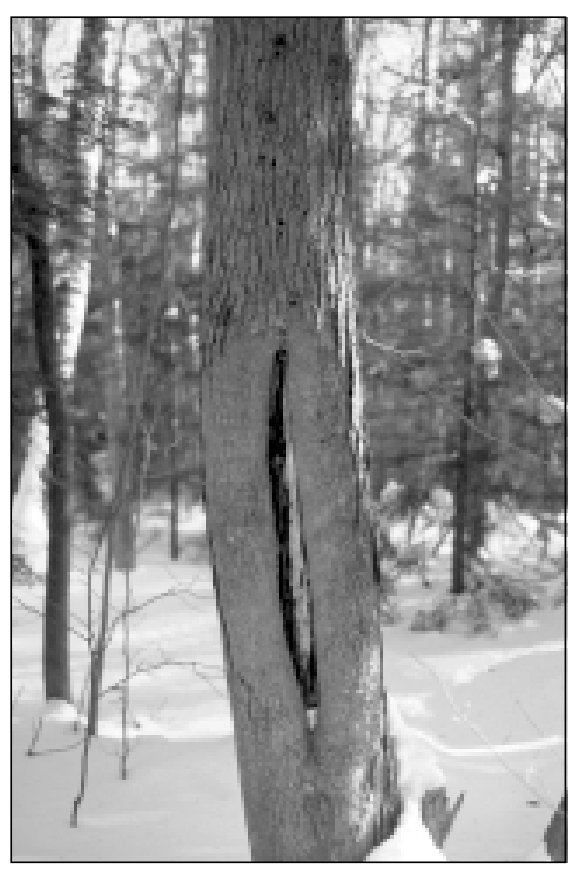

Figure 1. Typical treatment tree harvested to test toughness of woundwood and normal wood samples.

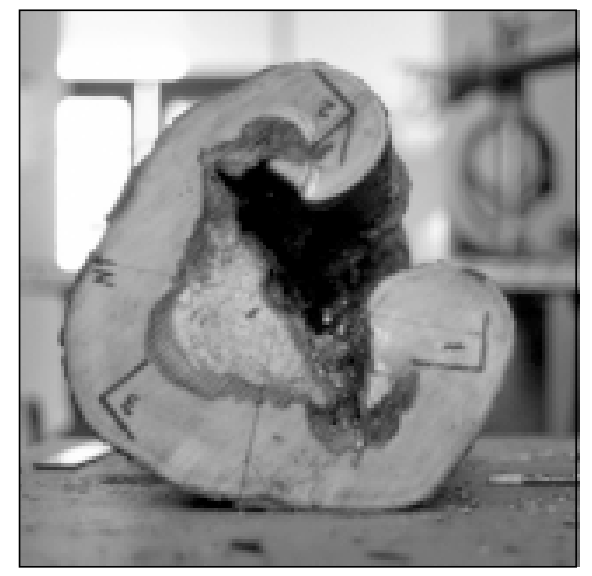

Figure 2. Typical treatment tree shown in cross section, including sample numbers and compass north. Samples 1 and 2 refer to $W 1$ samples, and sample 3 refers to $B 2$ samples in the text.

containing woundwood, named woundwood position one samples (W1); and one from opposite the wound, presumably containing barrier zone cells, but not woundwood, named barrier zone position two samples (B2) (Figure 2 and Figure 3). We did not perform an anatomical analysis of the samples. The samples were located by compass direction and were taken from the outermost growth rings. We also took three samples from the normal bolt of wood matched 


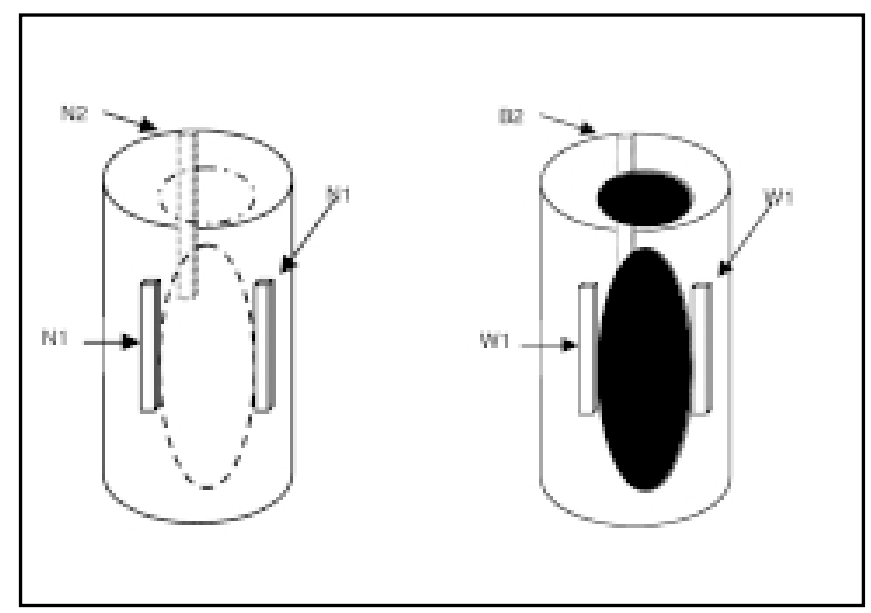

Figure 3. Line drawings show locations of samples taken from normal wood (left) and woundwood bolts from each tree. The dashed lines serve to reference the woundwood samples from the woundwood bolt.

in compass direction to the samples from the woundwood bolt; normal wood position one (N1) corresponded to (W1) samples, and normal wood position two (N2) corresponded to (B2) samples, respectively. The samples also came from the outermost growth rings, but we did not match individual growth rings of the matched samples.

Each sample was machined to exact dimensions according to the American Society for Testing and Materials (ASTM) D 6110-97 Standard Test Methods for Determining the Charpy Impact Resistance of Notched Specimens of Plastics (D 6110): $(1.27 \times 1.27 \times 12.7 \mathrm{~cm})($ ASTM 1999b) and tested the samples using the Charpy toughness test. We used the D 6110 standard test because it specifies a smaller sample size than ASTM D 143 (ASTM 1999a) or the European standard (DIN 52186) (DIN 1988). The toughness test for wood samples is an accepted and valuable method for determining mechanical properties of wood (Gerhards 1968; Bodig and Jayne 1982; ASTM 1999a). We tested all samples in the green condition.

For each sample, we measured toughness, basic specific gravity (oven-dry weight $\div$ green volume), growth rings, and grain angle. We rejected samples with grain angle greater than 5 degrees. In addition, we examined samples microscopically for the presence of tension wood, which exhibits different properties than normal wood and would confound the analysis. Finally, we photographed each woundwood bolt cross section and, using the photograph as a template for a cardboard cutout, calculated an approximate loss in I using the method described by Niklas (1992, p. 135). A more detailed description of this procedure is given in Kane and Ryan (in review).

We performed the following statistical analyses using SAS version 8: a univariate analysis of each measurement (toughness, specific gravity, and growth rings), significance tests [t-test or Wilcoxon's signed rank test (WSRT)] on differences between matched pairs for each measurement; and regressions of (1) toughness on specific gravity, (2) toughness on growth rings, (3) specific gravity on growth rings, and (4) change in toughness between woundwood and normal samples on loss in I. For data analysis, we used the mean of the samples that came directly from woundwood W1 and the matched normal wood samples N1. We used WSRT where data were not normally distributed.

To control for the effect of axial distance between woundwood and normal wood samples causing a change in toughness, we cut two bolts of normal wood from each control tree, separated by $12 \mathrm{~m}$. This was the average distance between woundwood and normal samples from treatment trees. From each bolt, we created four samples, one from each compass direction, and prepared and tested them in the same way as with the treatment samples.

\section{RESULTS}

Measurements of toughness, specific gravity, and growth for samples from each site were not statistically different: mean sample toughness for each site was $9.91 \mathrm{~N} * \mathrm{~m}$; mean of specific gravity of site 1 samples was 0.54 , and mean of site 2 samples was 0.55 ; mean sample growth rings for each site was 12 growth rings per $1.27 \mathrm{~cm}$. We discarded several samples that exhibited grain angle greater than 5 degrees. No samples exhibited a significant proportion of tension wood cells. Unless otherwise indicated, p values refer to WSRT.

Overall, woundwood samples were tougher than normal wood samples; significant differences between toughness measurements of $\mathrm{W} 1$ and B2 samples were also detected. The mean for $\mathrm{W} 1$ was $13.75 \mathrm{~N} * \mathrm{~m}$, and the mean for $\mathrm{N} 1$ was $9.91 \mathrm{~N} * \mathrm{~m}$. The mean toughness difference per tree between $\mathrm{Wl}$ and $\mathrm{N} 1$ was $4.3 \mathrm{~N} * \mathrm{~m}$, which was highly significant $(\mathrm{p}=0.0001)$. The mean for $\mathrm{B} 2$ was $10.75 \mathrm{~N} * \mathrm{~m}$, and the mean for $\mathrm{N} 2$ was $8.73 \mathrm{~N} * \mathrm{~m}$. The mean toughness difference per tree between $\mathrm{B} 2$ and $\mathrm{N} 2$ was $3.47 \mathrm{~N} * \mathrm{~m}$, which was highly significant $(p=0.002)$. The mean difference toughness per tree between $\mathrm{Wl}$ and $\mathrm{B} 2$ was $3.74 \mathrm{~N}^{*} \mathrm{~m}$, which was also highly significant ( $p=0.0009$ ). There was no significant difference in toughness between $\mathrm{N} 1$ and N2 samples, nor between $\mathrm{B} 2$ and $\mathrm{N} 1$ samples. Table 1 shows a summary of the toughness analysis.

Similarly significant differences were detected in specific gravity measurements. Woundwood samples had a higher specific gravity than normal wood samples; significant differences between specific gravity measurements from $\mathrm{W} 1$ and B2 samples were also detected. Mean specific gravity for $\mathrm{Wl}$ was 0.580 , and the mean for $\mathrm{N} 1$ was 0.537 . The mean difference per tree in specific gravity between $\mathrm{W} 1$ and $\mathrm{N} 1$ was 0.043 , which was highly significant $(\mathrm{p}<0.0001)$. The mean for $\mathrm{B} 2$ was 0.552 , and the mean for $\mathrm{N} 2$ was 
0.530 . The mean difference per tree in specific gravity between $\mathrm{B} 2$ and $\mathrm{N} 2$ was 0.018 , which was highly significant $(\mathrm{p}=0.0075)$. The mean difference per tree in specific gravity between $\mathrm{W} 1$ and B2 was 0.031, which was also highly significant $(\mathrm{p}=0.001)$. There was no significant difference in specific gravity between $\mathrm{N} 1$ and N2 samples. Table 2 shows a summary of the specific gravity analysis.

Analysis of growth ring data revealed significant differences in growth between $\mathrm{Wl}$ and $\mathrm{N} 1$ samples. Mean growth rings for $\mathrm{W} 1$ was 11.84 rings per $1.27 \mathrm{~cm}$; mean growth rings for $\mathrm{N} 1$ was 14.76 rings per $1.27 \mathrm{~cm}$. The mean of the differences was 3.25 rings per $1.27 \mathrm{~cm}$, which was significant (t-test, $\mathrm{p}=0.0196$ ), indicating that woundwood on average grew faster than normal wood. Mean growth rings for B2 was 12.23 rings per $1.27 \mathrm{~cm}$; mean growth rings for $\mathrm{N} 2$ was 14.15 rings per $1.27 \mathrm{~cm}$. The mean of the differences was 2.63 rings per 1.27 $\mathrm{cm}$, which was not significant $(\mathrm{p}=0.0527)$. No significant differences existed between $\mathrm{Wl}$ and B2 samples nor between $\mathrm{N} 1$ and $\mathrm{N} 2$ samples. Table 3 shows a summary of the growth ring analysis.

Results from control trees' samples did not support an effect due to axial distance between samples, which is not unexpected for red maple. Most deciduous species show no consistent pattern of variation of specific gravity with height in a stem (Panshin and DeZeeuw 1980). Neither toughness nor growth ring measures from control trees were significantly different between matched samples. An experimental error prevented analysis of specific gravity measures from control trees.

We transformed the data for the regression of toughness on specific gravity by taking the natural logarithm of each to facilitate a simple linear regression analysis in SAS. The fixed tree effect model had an $\mathrm{R}^{2}$ value of 0.83 and a root mean square error of 0.24. Considering a tree as a fixed effect, $\ln$ (toughness) was highly significantly affected by $\ln$ (specific gravity) in samples B2 ( $=0.0091), \mathrm{N} 1(\mathrm{p}<0.0001)$, and N2 ( $=$ $0.0014)$. The effect of $\ln$ (specific gravity) on ln(toughness) in W1 samples, however, was not significant ( $\mathrm{t}$-test, $\mathrm{p}=0.0714$ ). These results indicate that changes in specific gravity explain a significant portion of the change in toughness measurements except for $\mathrm{Wl}$ samples.

Considering the tree as a fixed effect, and
Table 1. Summary of toughness data; underlined $p$-values are significant at $\alpha \leq 0.01$.

\begin{tabular}{|c|c|c|c|c|c|}
\hline Toughness & $\mathrm{Wl}$ & B2 & W1 v. B2 & $\mathrm{N} 1$ v. N2 & $\mathrm{B} 2$ v. N1 \\
\hline Mean woundwood & 13.75 & 10.75 & & & \\
\hline Mean normal & 9.91 & 8.73 & & & \\
\hline Mean $\Delta$ /tree & 4.30 & 3.47 & 3.74 & 1.04 & 0.91 \\
\hline $\mathrm{SE} \Delta /$ tree & 0.842 & 0.964 & 0.919 & 0.590 & 0.972 \\
\hline p-value & $\underline{0.0001}$ & $\underline{0.002}$ & $\underline{0.0009}$ & ns & ns \\
\hline $\mathrm{n}$ (pairs) & 17 & 13 & 17 & 14 & 20 \\
\hline
\end{tabular}

Table 2. Summary of specific gravity data; underlined p-values are significant at $\alpha \leq 0.01$.

\begin{tabular}{llllll}
\hline Specific gravity & W1 & B2 & W1 v. B2 & N1 v. N2 & B2 v. N1 \\
\hline Mean woundwood & 0.580 & 0.552 & & & \\
Mean normal & 0.537 & 0.530 & & & \\
Mean $\Delta$ tree & 0.043 & 0.018 & 0.031 & 0.008 & 0.0645 \\
SE $\Delta$ tree & 0.008 & 0.006 & 0.008 & 0.007 & 0.038 \\
p-value & $\underline{0.0001}$ & $\underline{0.0075}$ & $\underline{0.0010}$ & ns & ns \\
n (pairs) & 18 & 17 & 20 & 18 & 20 \\
\hline
\end{tabular}

Table 3. Summary of growth ring per $1.27 \mathrm{~cm}$ data; underlined p-values are significant at $\alpha \leq 0.05$.

\begin{tabular}{llllll}
\hline Growth rings & W1 & B2 & W1 v. B2 & N1 v. N2 & B2 v. N1 \\
\hline Mean woundwood & 11.84 & 12.23 & & & \\
Mean normal & 14.76 & 14.150 & & & \\
Mean $\Delta$ tree & -3.250 & -2.625 & -0.056 & 0.417 & -2.619 \\
SE $\Delta$ /tree & 1.262 & 1.395 & 1.738 & 1.015 & 1.742 \\
p-value & $\underline{0.0196}$ & ns & ns & ns & ns \\
n (pairs) & 18 & 16 & 18 & 18 & 21 \\
\hline
\end{tabular}

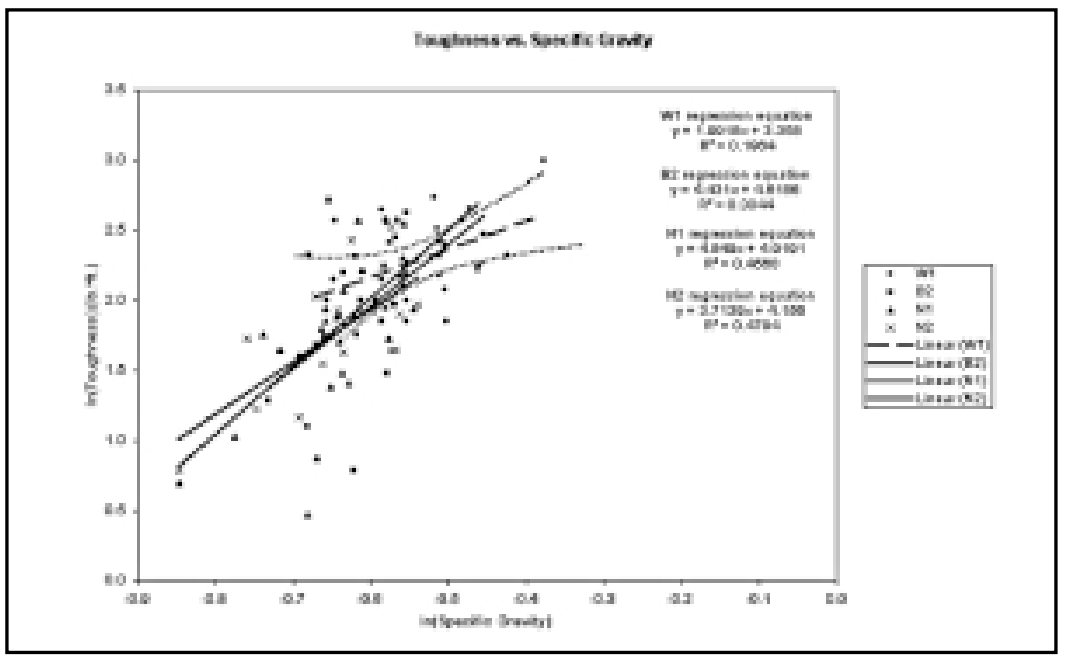

Figure 4. Scatter diagram and best fit lines from regression of each sample's toughness (natural log transformed) on sample specific gravity (natural log transformed). The dashed line corresponds to W1 samplesthe only samples where specific gravity did not significantly account for toughness variation. The dotted lines indicate upper and lower 95\% confidence limits for the $\mathrm{Wl}$ regression line. 
comparing the slopes of the regression lines of $\ln$ (toughness) on $\ln ($ specific gravity), the only significant difference occurred between $\mathrm{Wl}$ and $\mathrm{N} 1$ samples. The difference in regression coefficients $\left(\beta_{\mathrm{w} 1}-\beta_{\mathrm{N} 1}\right)$ was -2.58 $(1.62-4.20)$, indicating that the slope of the regression line relating $\ln$ (toughness) and $\ln$ (specific gravity) for $\mathrm{N} 1$ samples was significantly greater than the slope of the regression line relating $\ln$ (toughness) and $\ln$ (specific gravity) for $\mathrm{Wl}$ samples $(\mathrm{p}=0.0211)$. The results indicate a significant difference in the effect of specific gravity on toughness between W1 samples and N1 samples. Figure 4 shows scatter plots and best fit lines for the regressions by sample. Although p values changed slightly, modeling the tree effect as random did not change any significance results from the fixed effect model in the regression analysis.

The $\mathrm{R}^{2}$ value for the regression of $\ln$ (toughness) on $\ln$ (specific gravity) including a fixed tree effect $\left(R^{2}=0.83\right)$ varies from just under two to just over three times greater than $\mathrm{R}^{2}$ values for regressions of $\ln$ (toughness) on $\ln$ (specific gravity) for each sample (W1, B2, N1, N2) that do not account for a tree effect. The difference between the $\mathrm{R}^{2}$ values illustrates the importance of tree effect on the dependence of sample toughness on sample specific gravity. The $\mathrm{R}^{2}$ differences are greatest when comparing $\mathrm{Wl}$ samples [0.83 (fixed tree) vs. 0.25 (no tree effect)] and B2 samples [0.83 (fixed tree) vs. 0.31 (no tree effect)].

Regressions of toughness on growth rings did not produce any significant results, indicating that changes in toughness could not be explained by changes in growth rate. Similarly, regressions of specific gravity on growth rings did not produce any significant results, indicating that changes in specific gravity could not be explained by changes in growth rate. This was true of analyses considering tree as either a fixed or a random effect.

Regression analysis of the change in toughness between $\mathrm{W} 1$ and $\mathrm{N} 1$ and $\mathrm{B} 2$ and $\mathrm{N} 2$ samples and the maximum loss in I for the tree stem from which the matched samples were taken revealed no correlation. $\mathrm{R}^{2}$ values for all of the comparisons were less than 0.10 . The data do not show any meaningful dependence of improvement of woundwood sample toughness on the loss in I (and the expected increase in a) for each tree stem. We should note, however, that the loss in I was determined at one height for each tree. The woundwood samples did not necessarily come from the exact same height but would not have ranged farther than $20.3 \mathrm{~cm}$ from the height of the loss in I calculation. The loss in I calculation did not differ dramatically over that axial distance for any treatment tree.

\section{DISCUSSION}

There are at least two plausible explanations for the observed improvements in toughness: (1) anatomical and other changes in woundwood (not barrier zone cells) improve toughness by default; and (2) trees respond to $\sigma$ gradients by increasing toughness of woundwood formed in the region of a $\sigma$ concentration. Woundwood and barrier zone cells prevent discoloration and decay from penetrating wood formed after a wound. To serve this function, both woundwood and barrier zone cells are anatomically and chemically different than normal wood (Shigo 1977, 1979; Blanchette 1992). Another purpose that woundwood may serve is to increase the resistance of the wood around a wound to $\sigma$. Wounding initiates the decay process, potentially creating a $\sigma$ concentration on the tree by reducing I where the decay forms. Trees add wood to increase I where a $\sigma$ concentration exists, according to the adaptive growth hypothesis (Wood 1995). Another means of reducing the chance of failure at the weak spot on the trunk is to make the wood around the weak spot stronger, and thus able to withstand more $\sigma$ than normal wood.

Since Wl samples come from immediately adjacent to the open cavity or wound face, they are expected to endure the greatest $\sigma$. If the tree responds to a $\sigma$ concentration by improving its material properties in the vicinity of the $\sigma$, these samples should show the highest toughness measures, which they do. Samples B2 come from an area on the tree trunk where $\sigma$ is not as high as immediately around the open cavity but still would be higher than the region from which normal samples were taken (i.e., where no decay or open cavity existed). As a result, we expected the toughness observations from the samples to be lower than for W1 samples, but higher than N2 samples, which they are. Since there are no $\sigma$ concentrations in the regions from which normal wood samples were taken, we expected the samples to have the lowest toughness observations, which they did. Because $\sigma$ is expected to be roughly the same in the region from which $\mathrm{N} 1$ and $\mathrm{N} 2$ samples were taken, we neither expected nor observed differences in toughness between them. However, the lack of significant difference between $\mathrm{B} 2$ and N1 toughness values does not conform to this model because B2 samples presumably would endure greater stress than N1 samples. This casts doubt on the mechanical explanation for differences in toughness measures between matched sample pairs.

The hypothesis of uniform stress suggests that trees grow to create a uniform stress distribution throughout their structure. In other words, there are neither weak links nor wasted material in the structure of a tree (Mattheck and Breloer 1998). The idea that wood strength improves where $\sigma$ is high to compensate for the increase in $\sigma$ has been submitted (Mattheck and Bethge 1998). Our results do not support the contention that trees improve wood strength in response to $\sigma$. This is shown by both the lack of correlation between degree of woundwood toughness improvement and the degree of loss in I for each tree and by the lack of significant difference between B2 and N1 toughness values. 
We must stress, however, that the small sample size and homogeneity of sites from which samples were taken preclude extrapolation of our results beyond red maples growing in Massachusetts or New England.

Our results contrast Mattheck and Bethge's (1998) findings, which showed improved material properties with increased $\sigma$. The method they used to determine material properties, the Fractometer, was different from our methods, which may have contributed to the discrepancy. In addition, using the loss in I to represent the increase in $\sigma$ each tree would have endured is not entirely accurate. The load is an important variable in calculating $\sigma$ on the tree stem, and it was not included in this research (nor was it included in Mattheck and Bethge's (1998) study). Since the trees we tested were both similarly exposed to wind and similarly proportioned in terms of crown and stem sizes, we assumed that $\sigma$ was roughly similar among trees. In other words, larger-diameter trees had proportionately larger crowns than smaller-diameter trees. All but one of the trees was a dominant canopy tree. It is possible that tree loading was sufficiently different to cause changes in woundwood toughness that could not be explained by looking only at the loss in I as a measure of increased stem $\sigma$, but this did not seem likely.

The data seem to support better the second explanation for observed improvements in toughness, that the presence of anatomically different woundwood cells improves toughness by default. If woundwood were inherently tougher than normal wood because of anatomical differences, then the samples with the highest percentage of woundwood cells (W1) would be the toughest, which they were. Similar growth rates of $\mathrm{W} 1$ and B2 samples indicate that similar proportions of woundwood and barrier zone cells, respectively, occur in the samples. This highlights potential anatomical differences between woundwood and barrier zone cells as the explanation for toughness differences between $\mathrm{W} 1$ and B2 samples. Since the B2, N1, and N2 samples do not have any woundwood cells, they were expected to exhibit lower toughness observations, which they did. Although barrier zone cells return to normal in the circumferential direction more quickly than they return to normal in the longitudinal direction of the tree trunk, except in the woundwood immediately around a wound (Blanchette 1992), the short axial distance between woundwood and normal wood samples could have negated this. This would explain the significant difference between B2 and N2 sample toughness, since N2 samples would have the smallest proportion of barrier zone cells because they were farthest from the wound. It would also explain why there are no significant differences between B2 and N1 sample toughness and between N1 and N2 sample toughness. We expect a diminishing proportion of barrier zone cells in B2, N1, and N2 samples, in that order. In hindsight, not determining the proportion of woundwood and barrier zone cells in each sample was an important oversight.
The significance of tree effect in regressing $\ln$ (toughness) on $\ln$ (specific gravity) shows how other factors such as genetics, micro-environmental conditions, and tree age can influence wood properties. Since growth rate did not significantly influence toughness measures, and since mean sample growth rings were not significantly different between sites, it appears that genetics may be the most important factor in explaining the variation in tree response to wounding in the form of woundwood toughness improvement (assuming load was not a factor). Mattheck et al. (1995) suggested that trees exhibit a "fighting spirit," as reflected in wood quality improvements around a $\sigma$. Trees exhibiting the "will to live" by improving wood properties at areas of a present less of a hazard than trees that do not. The "fighting spirit" of a tree may be genetically programmed and would agree with the results of our research that show a high among-tree variability pertaining to woundwood toughness improvement.

We did find evidence of adaptive growth in the faster growth rate of $\mathrm{Wl}$ over $\mathrm{N} 1$ samples, as the woundwood grew around the wound. While it appears counterintuitive, faster growth of woundwood has not been shown to retard the spread of decay (Garrett et al. 1979; Shigo 1986, as cited in Blanchette 1992). On the other hand, many studies have shown that plants respond to mechanical loads (and the resulting $\sigma$ ) by changing their shapes and material properties (Holbrook and Putz 1989; Mattheck 1991; Jaffe and Forbes 1993; Telewski and Pruyn 1998; Pruyn et al. 2000). Despite the faster growth of woundwood, however, regressing change in growth rate with loss in I produced no correlation. Once again, genetic factors may be influencing a tree's ability to add new wood adaptively. Complications arise in the lack of differences between the growth rates of both $\mathrm{W} 1$ and $\mathrm{B} 2$ and $\mathrm{B} 2$ and $\mathrm{N} 1$ samples. $\mathrm{W} 1$ and $\mathrm{B} 2$ samples growing at the same rate suggests that the tree is adding wood at the region of mechanical stress. However, $\mathrm{B} 2$ growing at the same rate as $\mathrm{N} 1$ samples cannot be explained in the same way. The lack of differences appears to be due to the proportion of barrier zone cells in B2 and $\mathrm{N} 1$ samples, but this is not perfectly clear without an anatomical analysis.

We should also consider the results in light of the safety factor (SF) of a tree. It is not clear that a uniform SF exists for all trees. Niklas (2000) found that the SF varied with height from the top of the tree and, for wind speed of 20 $\mathrm{m} / \mathrm{s}$, approached 1 near the base of a black cherry (Prunus serotina). Mattheck and Breloer (1998) suggested a SF of 4.5 for tree trunks. For a SF of 2.5, none of the experimental trees endured a large enough increase in $\sigma$ (due to loss in I from decay) to exceed the SF (calculated as $\sigma_{\text {maximum }} / \sigma_{\text {working }}$ ). One tree experienced a twofold a increase, without a significant increase in woundwood toughness to mitigate the $\sigma$ concentration-still below the SF of 2.5. This could explain why all of the experimental trees remained standing 
in spite of high loss in I values for some trees (see Kane and Ryan, in review, for discussion of this topic).

The presence of a high SF in trees would make strength loss formula estimates even more conservative, in addition to the increase in woundwood toughness around wounds. However, to assume a uniform safety factor may be dangerous given recent evidence to the contrary (Niklas 2000) and without considering stem loading (Wessolly 1995). Loading endured by experimental trees is probably equally responsible for some trees remaining standing in spite of large values for loss in I. The SF calculated when wind speed reached $50 \mathrm{~m} / \mathrm{s}$ fell below 1 near the base of the tree in Niklas' (2000) study, in keeping with Wessolly's (1995) concerns about not accounting for load conditions when developing a SF. This is exactly the region where the largest values for loss in I occurred on many treatment trees in our research. We thus suggest that the load on the trees had not exceeded the maximum bending moment the trees could endure and the improved woundwood toughness offered an additional margin of safety.

\section{CONCLUSIONS}

Our findings indicate that improvement of woundwood toughness in red maple trees may counteract, to some degree, the loss in I that results from decay in a tree stem. Because of the lack of correlation between change in toughness and degree of loss in I, however, we cannot provide a simple model to advise arborists on risk assessment of trees with decayed trunks.

Forest-grown red maples in Massachusetts increase the toughness of wood formed around decay areas and open cavities. Substituted for a MOR value, the average increase in toughness suggests that, all other factors being equal, the strength loss formulas would overestimate the hazard presented by most of the trees we examined. This can lead to premature tree removal. Conversely, it adds to the safety factor of trees, albeit not consistently. We also caution that more studies are needed before assuming all trees react similarly to the trees we studied and arborists should not extrapolate our results beyond red maples growing in Massachusetts. Kane and Ryan (in review) examine another potential shortcoming of the strength loss formulas that should be considered in conjunction with the conclusions drawn in this paper.

We must remember that hazard tree evaluation is still more an art than a science, and experience plays a major role in an arborist's decision-making process. Although the results from this research highlight a limitation of hazard tree assessment practices, the research only addressed one component of the process. Far more studies of failure patterns, material properties, and techniques for hazard tree evaluation need to be performed. The variation in woundwood anatomy among species further complicates drawing conclusions before more species are tested for woundwood properties. There are simply too many variables to account for in trying to determine tree risk and only through further study can we begin to gain a better understanding of, and more precise thresholds for, when a tree becomes hazardous.

\section{LITERATURE CITED}

Albers, J., and E. Hayes. 1993. How to detect, assess and correct hazard trees in recreational areas. Minnesota Department of Natural Resources, St Paul, MN. 63 pp.

American Society for Testing and Materials. 1999a. D 143 Standard for Testing Small Clear Pieces of Wood. Annual Book of ASTM Standards, Part 16. ASTM, West Conshohocken, PA.

1999b. D 6110-97 Standard Test Methods for Determining the Charpy Impact Resistance of Notched Specimens of Plastics. Annual Book of ASTM Standards Vol. 8.03. ASTM, West Conshohocken, PA.

Blanchette, R.A. 1992. Anatomical responses of xylem to injury and invasion by fungi, pp 76-95. In Blanchette, R.A., and A.R. Biggs (Eds.). Defense Mechanisms of Woody Plants Against Fungi. Springer-Verlag, New York, NY.

Bodig, J., and B.A. Jayne. 1982. Mechanics of Wood and Wood Composites. Van Nostrand Reinhold, New York, NY. 712 pp.

DIN Deutsches Institut für Normung e.V. 1988. Normen über Holz. DIN Taschenbuch 31, 5th edition. Beuth, Berlin, Germany.

Forest Products Laboratory. 1999. Wood HandbookWood as an Engineering Material. Gen. Tech. Rep. FPLGTR-113. USDA, Forest Products Laboratory, Madison, WI. 456 pp.

Garrett, P.W., W.K. Randall, A.L. Shigo, and W.C. Shortle. 1979. Inheritance of Compartmentalization of Wounds in Sweetgum and Eastern Cottonwood. Forest Service Research Paper NE-443. USDAFS, Northeastern Forest Experiment Station, Durham, NH. 4 pp.

Gerhards, C.C. 1968. Effects of type of testing equipment and specimen size on toughness of wood. Research paper, FPL \#97. USDAFS For. Prod. Lab., Madison, WI. 14 pp.

Holbrook, N.M., and F.E. Putz. 1989. Influence of neighbors on tree form: Effects of lateral shade and prevention of sway on the allometry of Liquidambar styraciflua (sweet gum). Am. J. Bot. 76(12):1740-1749.

Jaffe, M.J., and S. Forbes. 1993. Thigmomorphogenesis: The effect of mechanical perturbation on plants. Plant Growth Regulat. 12:313-324.

Kane, B., and D. Ryan. In review. The accuracy of formulas used to assess strength loss due to decay in trees. J. Arboric.

Kane, B., D. Ryan, and D.V. Bloniarz. 2001. Comparing formulae that assess strength loss due to decay in trees. J. Arboric. 27(2):78-87. 
Lucas, R.C., et al. 1984. Outdoor Recreation Management, pp 801-886. In Wegner, K.F. (Ed). Forestry Handbook (2nd Ed). Wiley and Sons, New York, NY.

Matheny, N.P., and J.R. Clark. 1994. A Photographic Guide to the Evaluation of Hazard Trees in Urban Areas. International Society of Arboriculture, Champaign, IL 85 pp.

Mattheck, C. 1991. Trees: The Mechanical Design. SpringerVerlag, New York, NY. 121 pp.

Mattheck, C. and K. Bethge. 1998. The mechanical survival strategy of trees. Arboric. J. 22(4):369-386.

Mattheck, C., and H. Breloer. 1998. The Body Language of Trees. The Stationery Office. London, England, $240 \mathrm{pp}$.

Mattheck, C., H. Breloer, K.A. Bethge, W.A. Albrecht, and A.W. Zipse. 1995. Use of the Fractometer to determine the strength of wood with incipient decay. J. Arboric. 21(3):105-112.

Mills, L.J., and K. Russel. 1981. Detection and correction of hazard trees in Washington's recreation areas. DNR Report No. 42. Washington State Department of Natural Resources, Olympia, WA. 37pp.

Niklas, K.J. 1992. Plant Biomechanics: An engineering approach to plant form and function. University of Chicago Press, Chicago, IL. 607 pp.

2000. Computing factors of safety against windinduced tree stem damage. J. Exp. Bot. 51(345):797-806.

Panshin, A.J., and C. DeZeeuw. 1980. Textbook of Wood Technology (4th Ed.). McGraw-Hill, New York, NY. 722 pp.

Pruyn, M.L., B.J. Ewers III, and FW. Telewski. 2000.

Thigmomorphogenesis: Changes in the morphology and mechanical properties of two Populus hybrids in response to mechanical perturbation. Tree Physiol. 20(8):535-540.

Robbins, K. 1986. How to Recognize and Reduce Tree Hazards in Recreation Sites. USDA Forest Service, Northeastern Area, St. Paul, MN. 28 pp.

Shigo, A.L. 1977. Compartmentalization of Decay in Trees. Agriculture Information Bulletin No. 405. USDA Forest Service. 73 pp.
1979. Tree decay: An Expanded Concept. Agriculture Information Bulletin No. 419. USDA Forest Service. 73 pp.

Telewski, F.W., and M.L. Pruyn. 1998.

Thigmomorphogenesis: A dose response to flexing in Ulmus americana seedlings. Tree Physiol. 18(1):65-68.

Wagener, W.W. 1963. Judging hazards from native trees in California recreational areas: A guide for professional foresters. USFS Research Paper PSW-P1, 29 pp.

Wessolly, L. 1995. Fracture diagnosis of trees-Part 1: Statics-integrated methods-Measurement with tension test. Stadt Grün 6:416-422.

Wood, C.J. 1995. Understanding wind forces on trees, pp 133-163. In Coutts, M.P., and J. Grace (Eds.). Wind and Trees, Cambridge University Press Cambridge, England.

Acknowledgments. We received generous support from the State Farm Insurance Companies Foundation through a Doctoral Dissertation Award and from the International Society of Arboriculture through a John Duling Grant. We would like to thank Tom Smiley and two anonymous reviewers for helpful comments on an earlier version of this manuscript. Dan Pepin of the Department of Natural Resources Conservation at the University of Massachusetts machined the samples we tested.

${ }^{1 *}$ Assistant Professor of Arboriculture and Urban Forestry 230A Cheatham Hall (0324)

Virginia Tech University

Blacksburg, VA 24601, U.S.

bckane@vt.edu

${ }^{2}$ Professor of Arboriculture and Urban Forestry

Holdsworth Hall

University of Massachusetts at Amherst

Amherst, MA 01003, U.S.

*Corresponding author. 
Résumé. Les arbres dangereux sont une préoccupation pour toute personne qui a à gérer des arbres en milieu aménagé, et ce incluant les arboriculteurs, les forestiers urbains et les gestionnaires sur le terrain. Avec la recherche, l'expérience, l'observation et le gros bon sens, les arboriculteurs et les forestiers urbains ont identifié plusieurs facteurs de risques qui prédisposent les arbres à se briser. Ils ont aussi développé des seuils pour déterminer le degré de risques, si un arbre est en danger imminent ou non de tomber ou s'il a besoin d'inspection annuelle (ou plus fréquente). Deux facteurs critiques sont impliqués dans l'évaluation de la perte de résistance des arbres avec des défauts. Premièrement, il est important de connaître combien de perte de résistance est dû à un défaut comme une cavité. En second, la charge requise pour causer le bris est aussi à considérer étant donné que le bois de certains arbres peut supporter de plus grands stress mécaniques que d'autres. Des tests de bois de zones blessées et de bois sain dans des érables rouges du Massachusetts ont montré que le bois de zones blessées avait de plus grandes mesures de résistance comparativement au bois normal. Néanmoins, il n'y a pas de corrélation entre le degré de résistance amélioré du bois de zones blessées et la sévérité de la carie (calculée comme une perte de moment d'inertie dans la tige). L'amélioration de la résistance du bois de zones de blessées apparaît être un facteur additionnel de sécurité chez l'érable rouge (Acer rubrum) qui réduit le risque de bris en raison de la carie dans le tronc.

Zusammenfassung. Defektbehaftete Bäume sind immer ein Problem für alle, die mit Baummanagement zu tun haben, einschließlich Baumpfleger, Förster und Parkleiter. Durch Forschung, Erfahrung, Beobachtung, gesunden Menschenverstand haben Baumpfleger und Förster viele Risikofaktoren identifiziert, die Bäume dem Versagen aussetzen. Sie haben auch Schwellenwerte entwickelt, um den Risikofaktor des Versagen, ob ein Baum ständig in gefahr schwebt oder ob jährliche Kontrollen erforderlich sind, zu bestimmen. 2 kritische Faktoren liegen im Stärkeverlust bei Stämmen mit großen Schäden. Zuerst ist es wichtig zu wissen, wie viel Stärke ist verloren gegangen durch eine Wunde in Form einer Kavität oder Hohlraum. Zweitens muß der erforderliche Lasteintrag zum Baumversagen miteinbezogen werden, denn das Holz einiger Baumarten kann größeren mechanischen Stress aushalten als andere Baumarten. Tests von Wundholz und normalem Holz bei Rotahorn in Massachusetts zeigten, dass das Wundholz mit wesentlich größerer Stabilität reagierte als das normale Holzgewebe. Trotzdem bestand keine Korrelation zwischen dem Grad an Stärkezuwachs im Wundholz und der Schwere der Verletzung. Die Stärke von Wundholz scheint ein zusätzlicher Sicherheitsfaktor bei Rotahorn zu sein, welcher das Risiko des Versagens durch Defekte reduziert.

Resumen. Los árboles de riesgo son una preocupación para cualquiera que maneja árboles en el paisaje, incluyendo arbolistas, dasónomos urbanos y urbanistas. A través de la investigación, la experiencia, la observación y el sentido común de arbolistas y dasónomos urbanos, se han identificado muchos factores de riesgo que predisponen los árboles a fallar. También se han desarrollado umbrales para ayudar a determinar el grado de peligro, bien sea que el árbol esté en inminente riesgo de caer o las necesidades de inspecciones anuales (o más frecuentes). Dos factores críticos están implicados en los troncos con defectos. Primero, es importante conocer qué tanta resistencia del árbol se pierde debido a un defecto tal como una cavidad. Segundo, se necesita considerar la carga requerida para ocasionar una falla debido a que la madera de algunos árboles puede soportar mayor estrés mecánico que otros. Las pruebas con madera en decaimiento y madera normal en maple rojo de Massachussets mostró que la madera de la cavidad exhibió consistentemente mayor dureza comparada con la normal. No hubo, sin embargo, correlación entre el grado de dureza y la severidad del decaimiento (calculado como la pérdida en momento de inercia del tallo). El mejoramiento de la dureza de la madera de la cavidad parece ser un factor de seguridad adicional en maple rojo, que reduce el riesgo de falla debido al decaimiento del tronco. 